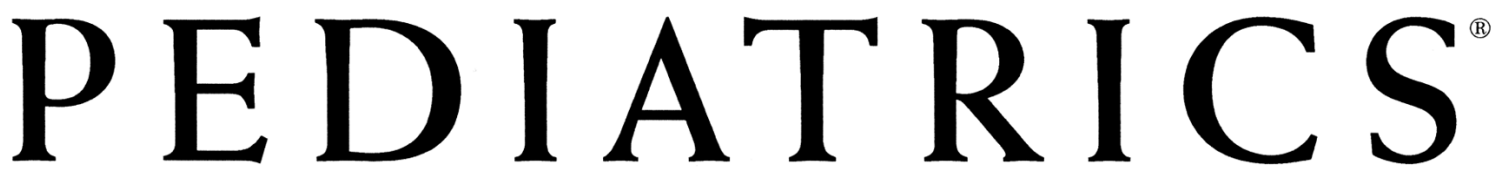

OFFICIAL JOURNAL OF THE AMERICAN ACADEMY OF PEDIATRICS

\title{
Treatment With Highly Active Antiretroviral Therapy in Human Immunodeficiency Virus Type 1-Infected Children Is Associated With a Sustained Effect on Growth
}

\author{
Gwenda Verweel, Annemarie M. C. van Rossum, Nico G. Hartwig, Tom F. W. Wolfs,
} Henriëtte J. Scherpbier and Ronald de Groot

Pediatrics 2002;109;25-

DOI: $10.1542 /$ peds.109.2.e25

This information is current as of November 20, 2006

The online version of this article, along with updated information and services, is located on the World Wide Web at:

http://www.pediatrics.org/cgi/content/full/109/2/e25

PEDIATRICS is the official journal of the American Academy of Pediatrics. A monthly publication, it has been published continuously since 1948. PEDIATRICS is owned, published, and trademarked by the American Academy of Pediatrics, 141 Northwest Point Boulevard, Elk Grove Village, Illinois, 60007. Copyright $\odot 2002$ by the American Academy of Pediatrics. All rights reserved. Print ISSN: 0031-4005. Online ISSN: 1098-4275.

\section{American Academy of Pediatrics}




\title{
Treatment With Highly Active Antiretroviral Therapy in Human Immunodeficiency Virus Type 1-Infected Children Is Associated With a Sustained Effect on Growth
}

\author{
Gwenda Verweel, MD*; Annemarie M. C. van Rossum, MD*; Nico G. Hartwig, MD, PhD*; \\ Tom F. W. Wolfs, MD, PhD‡; Henriëtte J. Scherpbier, MD§; and Ronald de Groot, MD, PhD*
}

\begin{abstract}
Introduction. Growth failure is a common feature of children with human immunodeficiency virus type 1 (HIV-1) infection. Children who are treated with mono or dual nucleoside analogue reverse transcriptase inhibitor (NRTI) therapy show a temporary increase in weight gain and linear growth rate. In adults, protease-inhibitor-containing antiretroviral therapy is associated with a sustained weight gain and increased body mass index (BMI). Experience with protease inhibitors and growth in children is still limited. The data mainly deal with short-term effects on growth.

Objective. To evaluate the effect of highly active antiretroviral therapy (HAART) on growth in children with HIV-1 infection.

Design and Methods. We analyzed selected growth parameters, clinical data, and laboratory results as part of a prospective, open, uncontrolled, multicenter study to evaluate the clinical, immunologic, and virologic response to HAART consisting of indinavir, zidovudine, and lamivudine in children with HIV-1 infection. Height and weight were measured at $0,12,24,36,48,60,72,84$, and 96 weeks after initiation of HAART. Information about the children's growth before enrollment in the study was retrieved from the hospital medical records and/or the school doctor or health center. BMI was calculated. $z$ Scores were used to express the standard deviation (SD) in SD units from the Dutch reference curves for age and gender. Viral loads and $\mathrm{CD} 4^{+} \mathrm{T}$-cell counts were examined prospectively and related to these growth parameters. $z$ Scores were also calculated for $\mathrm{CD} 4^{+} \mathrm{T}$-cell counts to correct for age-related differences. A $z$ score of 0 represents the $\mathbf{P 5 0}$, which is exactly the age/sex-appropriate median. A height $z$ score of -1 indicates that a child's height is 1 SD below the age- and gender-specific median height for the normal population. Virologic responders were defined as those who either reached an undetectable viral load $(<500$ copies $/ \mathrm{mL})$ or had a $>1.5$ $\log$ reduction in viral load compared with baseline at week 12 after the initiation of HAART, which was maintained during the follow-up period.
\end{abstract}

From the *Department of Pediatrics, Division of Pediatric Infectious Diseases and Immunology, University Hospital Rotterdam/Sophia Children's Hospital, the Netherlands; †Department of Pediatrics, University Hospital Utrecht/Wilhelmina Children's Hospital, the Netherlands; and §Department of Pediatrics, Amsterdam Medical Center/Emma Children's Hospital, the Netherlands.

Received for publication May 1, 2001; accepted Sep 24, 2001.

Reprint requests to (R.dG.) Department of Pediatrics, Sophia Children's Hospital, Dr Molewaterplein 60, 3015 GJ Rotterdam, the Netherlands. E-mail: rdegroot@alkg.azr.nl

PEDIATRICS (ISSN 0031 4005). Copyright @ 2002 by the American Academy of Pediatrics.
Results. Patients. Twenty-four patients were included (age: $\mathbf{0 . 4 - 1 6 . 3}$ years at baseline), with a median HIV-1 RNA load of 105925 copies/mL (5.03 log), a median $\mathrm{CD}^{+} \mathrm{T}$-cell count of $0.586 \times 10^{9} / \mathrm{L}$ (median $z$ score: $-2.28 \mathrm{SD}$ ), a median height $z$ score of -1.22 , a median weight $z$ score of -0.74 , and a median baseline BMI $z$ score of -0.32 . Eleven patients were naive to antiretroviral therapy, and 13 patients had received previous treatment with NRTI monotherapy. Twenty children used indinavir and 4 children used nelfinavir as part of HAART.

Virologic and immunologic responses to HAART. Seventeen children were virologic responders, and 7 children were virologic nonresponders. In patients naive to NRTIs, median baseline viral loads were significantly higher than in pretreated patients. However, at weeks 48 and 96, there was no significant difference between the viral loads of both groups. At baseline, there was no significant difference in $\mathrm{CD} 4{ }^{+} \mathrm{T}$-cell $z$ scores between virologic responders and nonresponders or between naive and pretreated patients. During 96 weeks of HAART, the increase of $\mathrm{CD}^{+} \mathrm{T}$-cell $z$ score was significantly higher in responders than in nonresponders. The increase in $\mathrm{CD}^{+} \mathrm{T}$-cell $z$ score was not significantly different for naive and pretreated patients.

Height, weight, and BMI $z$ score changes. We found that there was a trend toward a significantly increased $z$ score change during 96 weeks of HAART compared with the $z$ score change before HAART initiation for height and weight, but not for BMI.

Growth and virologic response to HAART. When the data were analyzed separately for virologic responders and nonresponders, virologic responders showed significant increases in height and weight. The height and weight of virologic nonresponders did not change significantly. The BMI did not change significantly in responders or in nonresponders.

Growth and immunologic response to HAART. The increase of weight and BMI $z$ scores from baseline correlated positively with the $\mathrm{CD}^{+}{ }^{+} \mathrm{T}$-cell $\mathrm{z}$ score increase from baseline. It did not correlate with absolute $\mathrm{CD}^{+}$ T-cell count increase. Height $z$ score increase did not correlate with $\mathrm{CD} 4^{+} \mathrm{T}$-cell $z$ score or with absolute $\mathrm{CD} 4^{+}$ T-cell counts.

Growth and previous NRTI treatment. The height $z$ score decrease from week -48 to baseline was significantly larger in naive than in pretreated patients. The weight and BMI $z$ score change from week -48 to baseline was not significantly different for pretreated and naive patients. From baseline to week 96 , the height and weight $z$ score change increased significantly in naive patients but not in pretreated patients compared with the change from week -48 to baseline. The BMI $z$ score did 
not change significantly over 96 weeks of HAART for naive or pretreated patients.

Growth and clinical stage of infection. The clinical stage of infection according to the Centers for Disease Control and Prevention classification correlated negatively with the BMI $z$ score and the weight $z$ score at baseline but not with the height $z$ score. Thus, children with the most severe clinical disease had the lowest BMI and weight $z$ scores at baseline. The BMI $z$ score increased more in children with more advanced clinical infection at baseline, who had lower BMI at baseline. The clinical stage of infection did not correlate with the change in weight $z$ score from baseline to week 96 .

Conclusions. HAART has a positive influence effect on the growth of HIV-1-infected children. This effect is sustained for at least 96 weeks. Height and weight are favorably influenced in children in whom HAART leads to a reduction of the viral load of at least $1.5 \log$ or to $<500$ copies/mL and to an increase in the CD4 ${ }^{+} \mathrm{T}$-cell $z$ score. In contrast to the increase of the BMI in adults on HAART, BMI did not increase in all children effectively treated with HAART. BMI increased more in children with an advanced stage of infection and a poor nutritional status at baseline. Data from pretreated and naive patients were difficult to interpret, because the baseline characteristics of these 2 groups differed too much. Pediatrics 2002;109(2). URL: http://www.pediatrics.org/ cgi/content/full/109/2/e25; human immunodeficiency virus, acquired immunodeficiency syndrome, highly active antiretroviral therapy, protease inhibitor, growth, height, weight, body mass index.

ABBREVIATIONS. HIV-1, human immunodeficiency virus type 1; AIDS, acquired immunodeficiency syndrome; BMI, body mass index; HAART, highly active antiretroviral therapy; NRTI, nucleoside analogue reverse transcriptase inhibitor; SD, standard deviation.

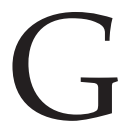
rowth failure is a common feature of children with human immunodeficiency virus type 1 (HIV-1) infection. ${ }^{1-8}$ The cause of this HIV-1related growth failure is complex. It is not only caused by an inadequate caloric intake, because increases in caloric intake do not seem to increase lean body mass or accelerate the rate of linear growth, but only increase weight and fat mass.9,10 A correlation with viral load was previously recognized. ${ }^{11}$ Abnormal function of the thyroid gland, the somatomedine axis, the lipid metabolism, and abnormal resting energy expenditure may also contribute to the diminished growth. ${ }^{12,13}$ Growth seems to be one of the most sensitive indicators of disease progression in children with acquired immunodeficiency syndrome (AIDS). The absence of growth indicates a poor prognosis, also in children who are treated with antiretroviral regimes. ${ }^{14-19}$ Poor growth commonly precedes a decline in $\mathrm{CD}^{+}{ }^{+} \mathrm{T}$-cell count and the subsequent development of opportunistic infections. $^{20,21}$ Several studies have shown that weight gain may be an important indicator of antiretroviral therapeutic efficacy. ${ }^{22,23}$ Children who are treated with mono or dual therapy containing zidovudine, didanosine, or zalcitabine show a temporary increase in weight gain and linear growth rate. ${ }^{24-26}$ In adults, protease-inhibitor-containing antiretroviral therapy is associated with a sustained weight gain and in- creased body mass index (BMI). ${ }^{27}$ Experience with protease inhibitors and growth in children is still limited; it mainly consists of short-term effects on growth. ${ }^{28-31}$ The objective of this study was to evaluate the effect of highly active antiretroviral therapy (HAART) consisting of 1 protease inhibitor and 2 nucleoside analog reverse transcriptase inhibitors (NRTIs) on the long-term growth profile of HIV-1infected children.

\section{METHODS}

Selected growth parameters, clinical data, and laboratory results were analyzed as part of a prospective, open, uncontrolled, multicenter study to evaluate the clinical, immunologic, and virologic response to HAART consisting of indinavir, zidovudine, and lamivudine in children with HIV-1 infection. ${ }^{32}$ The study protocol was approved by the medical ethical committees of all the participating centers. Written informed consent was obtained from parents or legal guardians. Children $>3$ months of age with HIV-1 infection and 1 of the following 2 items: a decreased $\mathrm{CD}^{+} \mathrm{T}$-cell count $\left(<1\right.$ year: $<1750 / \mathrm{mm}^{3}, 1-2$ years: $<1000 / \mathrm{mm}^{3}, 3-6$ years: $<750 / \mathrm{mm}^{3},>6$ years: $<500 / \mathrm{mm}^{3}$ ) or a HIV-1 viral load $>5000$ copies $/ \mathrm{mL}$ were included. Growth data before HAART initiation also needed to be available to be included. Height and weight measurements and blood samples for virologic and immunologic parameters were obtained twice within a month before the start of HAART, and after 12, 24, 36, 48, 60, 72, 84, and 96 weeks of treatment. Height and weight measurements were obtained by a single investigator using the same scales and the same metal measuring rod every time. Information about the children's growth before enrollment in the study was retrieved from the hospital medical records and/or the school doctor or health center. Height and weight measurements obtained closest to 24 and 48 weeks before HAART initiation were entered into the database.

Virologic responders were defined as those who either reached an undetectable viral load $(<500$ copies $/ \mathrm{mL})$ or had a $>1.5 \log$ reduction in viral load compared with baseline at week 12 after the initiation of HAART, which was maintained during the follow-up period.

The BMI was calculated from height and weight values as defined by BMI $=$ weight $(\mathrm{kg}) /(\text { height }(\mathrm{m}))^{2}{ }^{2}$ BMI provides an indication of the nutritional status of the patients. Compared with the 2 other measurements for weight-for-height, ie, $\mathrm{kg} / \mathrm{m}$ and $\mathrm{kg} / \mathrm{m}^{3}$, BMI has the desired lower correlation with height and higher correlation with weight and skinfold thickness. ${ }^{33} z$ Scores were used to express the deviation in standard deviation (SD) units from the Dutch reference curves for age and gender. ${ }^{34,35}$ The $z$ scores for weight, height, and BMI were calculated by means of the SDS software program (version 2.0, Erasmus University, Rotterdam, the Netherlands). Reference growth curves were not available for most countries from which the patients originated. Therefore, Dutch reference growth curves were used. Because we only discuss change in $z$ scores over time and not absolute $z$ scores, this does not present any problems. $z$ Scores were also calculated for $\mathrm{CD} 4{ }^{+} \mathrm{T}$-cell counts to correct for age-related differences. ${ }^{36} \mathrm{~A} z$ score of 0 represents the P50, which is exactly the age/sex-appropriate median. A height $z$ score of -1 indicates that a child's height is 1 SD below the age- and gender-specific median height for the normal population.

The viral load was measured using the Roche Amplicor HIV-1 Monitor test (Roche, Branchburg, NJ). ${ }^{37} \mathrm{CD}^{+} \mathrm{T}$-cell counts were obtained by standard flow cytometric methods. Statistical calculations were performed with the SPSS statistical analysis software program (SPSS Inc, Chicago, IL, version 10.0). The relations between growth parameters, $\mathrm{CD} 4^{+} \mathrm{T}$ lymphocyte counts, $\mathrm{CD}^{+} z$ scores, and viral loads were analyzed using the Wilcoxon signedrank test, Mann-Whitney $U$ test, and Spearman rank correlation test. All $P$ values are 2 -tailed.

\section{RESULTS}

\section{Population Characteristics}

Patients

Twenty-four HIV-1-infected children were included. They all completed at least 96 weeks of 
HAART. Baseline characteristics of these 24 children are presented in Table 1 . The median age of the children was 5.2 years (range: 4.6 months-16.3 years). Eleven patients were not previously treated and 13 had received previous treatment with NRTIs, mostly zidovudine mono therapy for an average of 30 months (range: 8.4-106.2 months). Pretreated children were significantly older at baseline than NRTInaive children $(P=.002)$, with a median age of 7.4 years and 2.0 years, respectively. Twenty children received HAART containing indinavir and 2 NRTIs and 4 children received HAART containing nelfinavir and 2 NRTIs. In 5 children, indinavir was changed to nelfinavir and in 1 child to indinavir and ritonavir and later to nevirapine because of a viral load rebound after a median duration of 48 weeks. In 2 other children, indinavir was changed to nelfinavir because of long-term side effects.

\section{Virologic Response}

The median baseline plasma viral load of $5.03 \log _{10}$ copies/mL (range: $2.43-5.88$ ) decreased to less than $2.70 \log _{10}$ copies/mL by week 48 and remained below the level of detection until at least week 96. In patients naive to NRTIs $(N=11)$ median baseline viral loads were significantly higher than in pretreated patients $(N=13 ; P=.02)$. However, at weeks 48 and 96 , there was no significant difference between the viral loads of both groups (Table 2).

Seventeen children were virologic responders and 7 children virologic nonresponders.

\section{Immunologic Response}

Absolute $\mathrm{CD}^{+}{ }^{+} \mathrm{T}$-cell counts per age group are shown in Fig 1A. The median baseline CD4 ${ }^{+}$T-cell $z$ score was -2.28 SD (range: -13.75-0.26). At base-

TABLE 1. Baseline Characteristics of Study Patients $(n=24)$

\begin{tabular}{|c|c|}
\hline Median age in years (range) & $5.2(0.4-16.3)$ \\
\hline Sex (male/female), $n$ & $11 / 13$ \\
\hline \multicolumn{2}{|l|}{ Race/ethnicity, $n$} \\
\hline Nonwhite & 19 \\
\hline White & 5 \\
\hline \multicolumn{2}{|l|}{ Route of acquisition, $n$} \\
\hline Vertical & 16 \\
\hline Blood products & 4 \\
\hline Unknown & 4 \\
\hline \multicolumn{2}{|l|}{ CDC classification $*, n$} \\
\hline $\mathrm{N} 1 / 2$ & $2 / 3$ \\
\hline A $1 / 2 / 3$ & $2 / 3 / 4$ \\
\hline B $1 / 2$ & $1 / 4$ \\
\hline C $2 / 3$ & $2 / 3$ \\
\hline No previous treatment, $n$ & 11 \\
\hline \multicolumn{2}{|l|}{ Previous treatment with, $n$} \\
\hline zidovudine & 11 \\
\hline zidovudine/zalcitabine & 2 \\
\hline $\begin{array}{l}\log _{10} \text { copies of HIV RNA/mL plasma, } \\
\text { median (range) }\end{array}$ & $5.03(3.42-5.87)$ \\
\hline $\begin{array}{l}\mathrm{CD}^{+} \text {cell count in } 10^{9} / \mathrm{L} \text {, median } \\
\text { (range) }\end{array}$ & $0.586(0.010-3.580)$ \\
\hline $\begin{array}{l}\mathrm{CD}^{+} z \text { score in } \mathrm{SD} \text {, median } \\
\text { (range) }\end{array}$ & $-2.28(-13.75-0.26)$ \\
\hline \multicolumn{2}{|l|}{$z$ Score in SD, median (range) } \\
\hline Height & $-1.22(-3.84-1.25)$ \\
\hline Weight & $-0.74(-3.13-2.26)$ \\
\hline BMI & $-0.32(-3.88-2.03)$ \\
\hline
\end{tabular}

* Clinical and immunologic categories as defined by the US Centers for Disease Control and Prevention (CDC). ${ }^{38}$ line, there was no significant difference between virologic responders and nonresponders or between naive and pretreated patients $(P>.05)$. During 96 weeks of HAART, the increase of $\mathrm{CD}^{+}$T-cell $z$ score was significantly higher in responders than in nonresponders $(P=.008$; Fig $1 \mathrm{~B})$. The increase in $\mathrm{CD} 4^{+}$ T-cell $z$ score was not significantly different for naive and pretreated patients $(P>.05)$.

\section{Height, Weight, and BMI $z$ Score Changes}

Using data from all patients regardless of virologic response and previous treatment, the effects of HAART on growth were determined. We found that the height $\mathrm{z}$ score decreased in the 48 weeks before HAART initiation with a median (range) of -0.088 SD $(-1.88-1.17)$ to a median of $-1.22 \mathrm{SD}$ at baseline. From baseline to 96 weeks after the initiation of HAART the height $z$ score increased with a median (range) of $0.20 \mathrm{SD}(-0.72-1.29)$ to a median of -0.95 SD. The weight $z$ score decreased from week -48 to baseline with a median (range) of -0.041 SD $(-4.10$ 1.96 ) to a median of -0.74 . From baseline to week 96 the weight $z$ score increased with a median of $0.34 \mathrm{SD}$ $(-0.83-2.13)$ to a median of -0.60 . The BMI $z$ score change from week -48 to baseline decreased with a median (range) of $-0.12 \mathrm{SD}(-4.10-1.96)$ to a median of -0.32 SD. From baseline to week 96 the median (range) BMI $z$ score change was $0.28 \mathrm{SD}(-1.75-3.60)$ to a median of $0.19 \mathrm{SD}$. We found that there was a trend toward a significantly increased $z$ score change during 96 weeks of HAART compared with the $z$ score change before HAART initiation for height $(P=.052)$ and weight $(P=.056)$, but not for BMI $(P=.627)$.

\section{Growth and Virologic Response to HAART}

The median change in height $z$ score decreased in the 48 weeks before HAART initiation. Children with a higher viral load at baseline showed a larger decrease $(P<.0001)$ of the height $z$ score in the 48 weeks before HAART initiation than children with a lower viral load. From baseline to week 96 height $z$ score and weight $z$ score changes increased significantly in virologic responders, but not in nonresponders compared with the change from week -48 to baseline (Fig 2A-D).

BMI $z$ score did not increase significantly over 48 or 96 weeks of HAART in responders or in nonresponders. (Fig 2, E and F) However, the BMI $z$ score change increased significantly more in virologic responders than in nonresponders to HAART $(P=.024$ after 96 weeks).

\section{Growth and Immunologic Response to HAART}

During 96 weeks of HAART, the change in height $z$ scores from baseline did not correlate with the change in $\mathrm{CD}^{+}{ }^{+} \mathrm{T}$-cell $\mathrm{z}$ scores or absolute $\mathrm{CD}^{+}$ T-cell counts.

The change in weight $z$ scores from baseline correlated positively with the change in $\mathrm{CD}^{+} \mathrm{T}$-cell $\mathrm{z}$ scores at week $24(r=0.693 ; P<.0001), 36(r=0.543$; $P=.007), 48(r=0.628 ; P=.001), 60(r=0.540 ; P=$ $.009), 84(r=0.496 ; P=.019)$ and $96(r=0.408 ; P=$ .048). The change in weight $z$ scores only correlated 
TABLE 2. Viral Load at Baseline, 48 Weeks and 96 Weeks after HAART Initiation in Log copies per mL, Median (25th and 75th Percentile)

\begin{tabular}{llll}
\hline \multicolumn{1}{c}{ Patients } & Baseline & Week 48 \\
\hline All & $5.03(4.29-5.60)$ & $<2.70(<2.70-<2.70)$ \\
Naive & $5.41(5.16-5.85)^{*}$ & $<2.70(<2.70-<2.70)$ & $<2.70(<2.70-3.29)$ \\
Pretreated & $4.47(4.09-4.93)^{*}$ & $<2.70(<2.70-2.76)$ & $<2.70(<2.70-2.85)$ \\
Responders & $5.16(4.32-5.66)$ & $<2.70(<2.70-<2.70) \dagger$ & $<2.70(<2.70-3.47)$ \\
Nonresponders & $4.94(4.24-5.29)$ & $<2.70(<2.70-<2.70) \ddagger$ & $3.29(3.08-4.34) \ddagger$ \\
\hline
\end{tabular}

* Significant difference, $P=.02$.

† Significant difference, $P=.024$.

$\ddagger$ Significant difference, $P<.0001$.
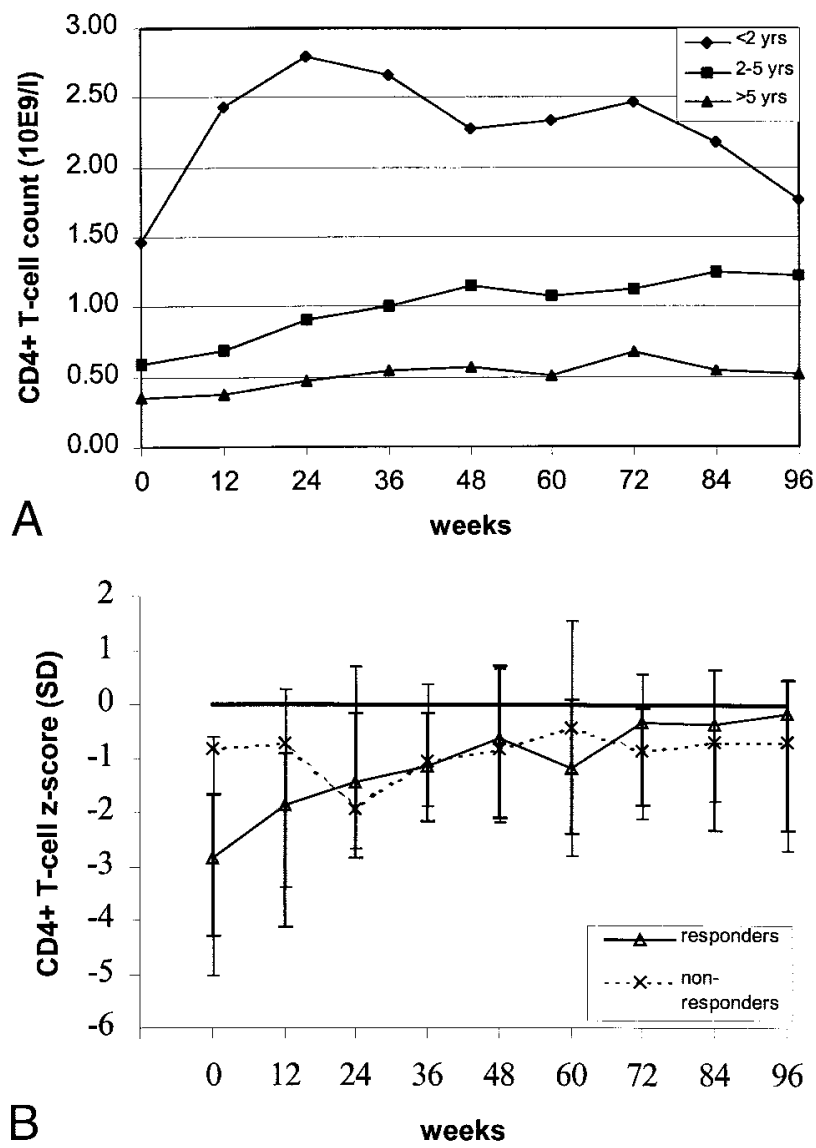

Fig 1. A, CD4 ${ }^{+} \mathrm{T}$-cell count change in different age categories during 96 weeks of HAART. B, CD4 ${ }^{+}$T-cell $z$ score change in responders and nonresponders during 96 weeks of HAART.

with the change in absolute $\mathrm{CD} 4^{+} \mathrm{T}$-cell counts at week $36(r=0.439 ; P=.032)$.

The change in BMI $z$ scores correlated positively with the change in $\mathrm{CD}^{+}{ }^{+} \mathrm{T}$-cell $z$ scores at al time points from week 12 onwards except at week 84: week $12(r=0.476 ; P=.019), 24(r=0.671 ; P<$ $.0001), 36(r=0.508 ; P=.011), 48(r=0.592 ; P=$ $.003), 60(r=0.443 ; P=.039), 72(r=0.520 ; P=.013)$, $84(r=0.369 ; P=.091)$ and $96(r=0.501 ; P=.013)$. The change in BMI $z$ scores did not correlate with change in absolute $\mathrm{CD} 4^{+} \mathrm{T}$-cell counts.

\section{Growth and Previous NRTI Treatment}

The height $z$ score decrease from week -48 to baseline was significantly larger in naive $(-0.41 \mathrm{SD})$ than in pretreated $(-0.04 \mathrm{SD})$ patients $(P=.007)$. From baseline to week 96 , the height $z$ score change increased significantly in naive patients $(P=.033)$ but not in pretreated patients compared with the change from week -48 to baseline.

The weight and BMI $z$ score change from week -48 to baseline was not significantly different for pretreated and naive patients. The weight $z$ score change increased significantly over 96 weeks of HAART for naive patients $(P=.026)$ but not for pretreated patients.

The BMI $z$ score did not change significantly over 96 weeks of HAART for naive or pretreated patients. There was no significant difference between naive and pretreated patients either.

\section{Growth and Clinical Stage of Infection}

The clinical stage of infection according to the Centers for Disease Control and Prevention classification $^{38}$ correlated negatively with the BMI $z$ score at baseline. Thus, children with the most severe clinical disease had the lowest BMI $z$ scores at baseline. The BMI $z$ score increased more in children with more advanced clinical infection at baseline, who had lower BMI at baseline.

The clinical stage of infection at baseline also correlated negatively with weight $z$ score but not with the height $z$ score. Children with advanced clinical infection had lower weight for their age and gender at baseline. The clinical stage of infection did not correlate with the change in weight $z$ score from baseline to week $96(P>.05)$.

\section{DISCUSSION}

The results of this study indicate that children with HIV-1 infection show a trend to an increase in height and weight $(P=.052, P=.056$, respectively) after the initiation of HAART. However, when the children were divided into virologic responder and nonresponder groups, the responders showed significant increases in height and weight, whereas nonresponders did not. The BMI did not change significantly in responders or in nonresponders, although it increased more in responders than in nonresponders. Increasing CD4 ${ }^{+} \mathrm{T}$-cell counts favorably influenced weight and BMI. Clinical stage of infection was also correlated with the increase of BMI from baseline to week 96 of HAART. BMI $z$ scores increased more in children with an advanced clinical stage of infection at initiation of HAART. The energy expenditure previously needed to combat infection was possibly used for catch-up growth. $\mathrm{CD}^{+}{ }^{+} \mathrm{T}$-cell $\mathrm{z}$ scores then relate to BMI and weight only indirectly.

In HIV-1-infected adults receiving HAART, BMI 

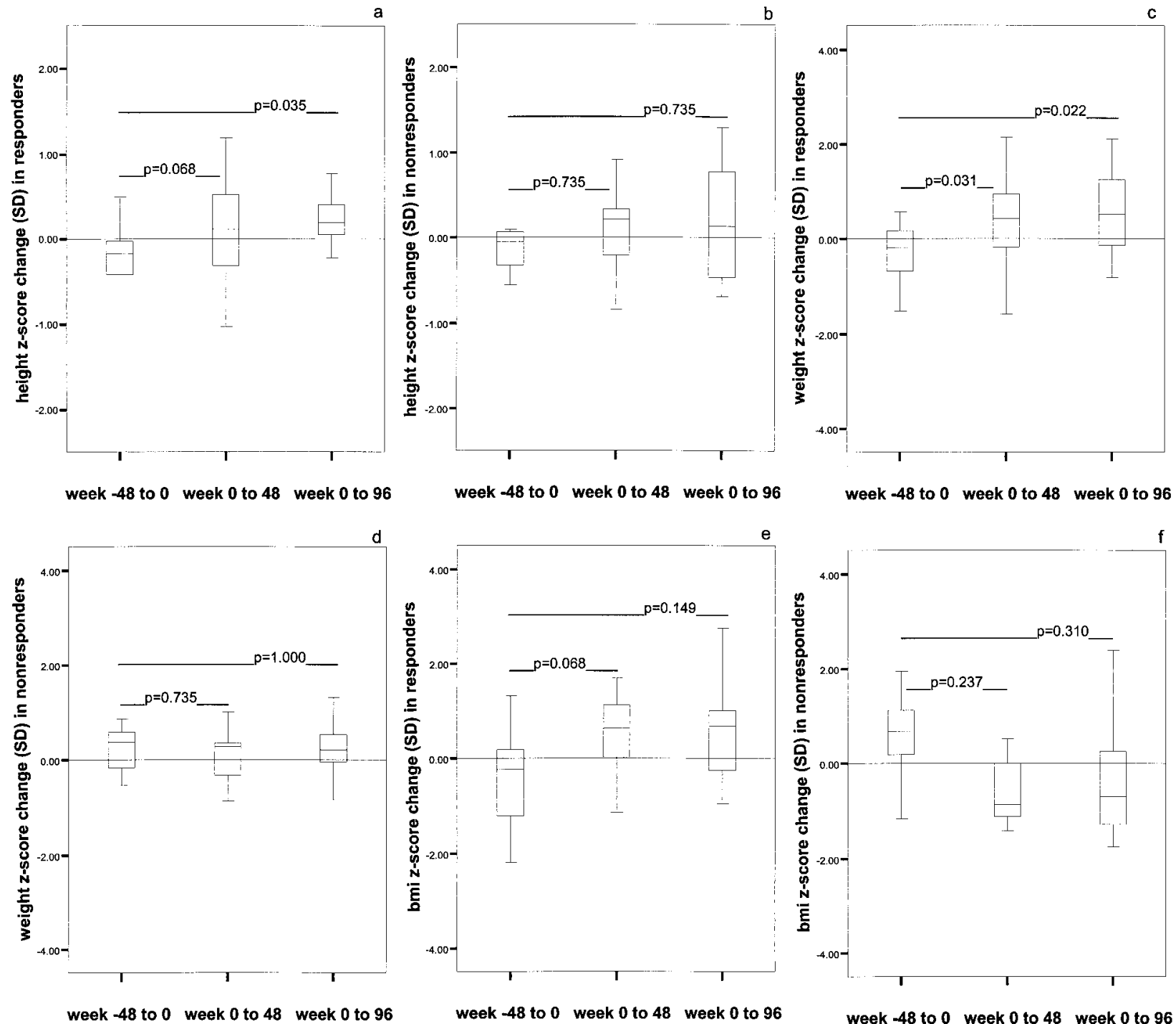

Fig 2. Growth before and during HAART in $(\mathrm{A}, \mathrm{C}$, and $\mathrm{E})$ responders and $(\mathrm{B}, \mathrm{D}$, and $\mathrm{F})$ nonresponders.

increased significantly more in responders than in nonresponders, but BMI also increased significantly overall in responders and in nonresponders. BMI increase consisted mainly of increased fat mass. Lean body mass did not increase significantly. ${ }^{27}$ We are not aware of any previously published studies on the influence of HAART on BMI in HIV-1-infected children. However, in a recent study in HIV-1-infected children, protease inhibitors were found to cause a significant increase in weight-for-height and a dramatic improvement in lean body mass over a short interval and had no immediate influence on fat mass, although there was a trend toward increased fat mass, with longer follow-up time. ${ }^{28}$ This suggests that in the children whose BMI increased in our study, namely the children with an advance stage of clinical infection and responders to HAART with a high increase in $\mathrm{CD} 4^{+} \mathrm{T}$-cell count, lean body mass also increased. The difference of the effect of HAART on body composition between children and adults could be attributed to the fact that children are still growing so their metabolism is different, but additional research is needed.
Height did not increase significantly in responders until week 96, whereas weight already increased significantly at week 48 . This is a normal reaction to the correction of a growth-retarding disorder: catch-up growth first affects weight followed by height. ${ }^{39}$

At the initiation of HAART, viral loads correlated negatively with height $z$ score change in the previous year and the clinical stage of infection correlated negatively with BMI $z$ score and weight $z$ score. Children with high viral loads and severe clinical infection also had poor grow parameters. These are all associated with a poor prognosis. Although the number or percentage of $\mathrm{CD} 4^{+} \mathrm{T}$ cells has a larger influence on prognosis, increasing growth rates also contribute to a better prognosis. ${ }^{16,18,19,22,23}$

Height and weight $z$ score change over 96 weeks compared with $z$ score change in the 48 weeks before HAART initiation increased more in responders than in nonresponders. It also increased more in naïve patients than in pretreated patients. Although this could be interpreted as a confounder, it is more likely to be the result of previous antiretroviral therapy. Pretreated patients seem to have already reached a 
higher height $z$ score change during the 48 weeks before HAART initiation. This may have been caused by the treatment with NRTIs. Weight $z$ score change in the 48 weeks before HAART initiation was not significantly different between naive and pretreated patients. We concluded from the observation that weights increased in naive patients and not in pretreated patients. However, a difference was observed in baseline viral load and age: pretreated patients were significantly older and had a significantly lower viral load. This complicates the comparison between these 2 groups of patients.

Similar results in height and weight gain as observed by our group were reported in 3 other studies on the effects of HAART in children. ${ }^{28,30,31}$ However, the follow-up time of these studies was only 24 weeks. A positive influence on growth has been observed as a result of NRTI mono therapy or dual therapy during this same period. ${ }^{14,22,24,40-46}$ The effect on growth of mono therapy cannot be sustained after 24 weeks of treatment. There is no data that supports that dual therapy has a sustained effect on growth beyond 24 weeks. The current study shows that the positive effects of HAART on growth can be sustained for at least 96 weeks. Therefore, the effect on growth lasts longer in patients receiving HAART than in patients receiving mono or duo reverse transcriptase inhibitor therapy. There seems to be a relation between the time that an antiretroviral therapy is successful in the suppression of viral load and the time that the positive effect on growth by this therapy can be maintained. Ogino et $\mathrm{al}^{22}$ also raised this point when they described the effect of zidovudine resistance on growth.

Dreimane et $\mathrm{al}^{29}$ retrospectively reviewed $27 \mathrm{HIV}$ 1-infected children receiving HAART for a mean follow-up time of 20 months. They also found increased $z$ scores for height and height-velocity, but not for weight. This difference in findings may be attributed to the low number of responders to HAART in their study (10 of 27) compared with the high number of responders (17 of 24) in our study. It could also be attributed to the fact that they used another protease inhibitor. Unfortunately, they did not mention which protease inhibitor was used in their patients. Miller et $\mathrm{al}^{28}$ found that ritonavir had a weaker effect on weight with a stronger effect on height compared with indinavir and nelfinavir.

\section{CONCLUSION}

HAART has a positive effect on height and weight in children with HIV-1 infection. This effect is sustained for at least 96 weeks and is associated with the successful application of HAART, resulting in longterm viral load reduction of at least $1.5 \log$ copies $/ \mathrm{mL}$ or viral load suppression below 500 copies $/ \mathrm{mL}$ and an increase of $\mathrm{CD}^{+}{ }^{+} \mathrm{T}$-cell counts. The sustained effects of HAART on growth may positively influence the child's quality of life and will predictably contribute to a better prognosis. The mechanism of increased growth during antiretroviral therapy is yet unknown. Contrary to the BMI increase in adults treated with HAART, BMI in children does not increase in all patients successfully treated with HAART, but only in those with a low BMI at initiation of HAART. More research is needed to investigate whether those factors causing growth failure in children with HIV-1 infection-caloric intake, thyroid and growth hormones, lipid metabolism, and resting energy expenditure-also play a role in the recovery of growth parameters during HAART.

\section{REFERENCES}

1. Laue L, Pizzo PA, Butler K, Cutler GB Jr. Growth and neuroendocrine dysfunction in children with acquired immunodeficiency syndrome [see comments]. J Pediatr. 1990;117:541-545

2. McKinney RE Jr, Robertson JW. Effect of human immunodeficiency virus infection on the growth of young children. Duke Pediatric AIDS Clinical Trials Unit. J Pediatr. 1993;123:579-582

3. Miller TL, Evans SL, Orav EJ, Morris V, McIntosh K, Winter HS. Growth and body composition in children infected with the human immunodeficiency virus-1. Am J Clin Nutr. 1993;57:588-592

4. Nair P, Alger L, Hines S, Seiden S, Hebel R, Johnson JP. Maternal and neonatal characteristics associated with HIV infection in infants of seropositive women. J Acquir Immune Defic Syndr. 1993;6:298-302

5. Matarazzo P, Palomba E, Lala R, et al. Growth impairment, IGF I hyposecretion and thyroid dysfunction in children with perinatal HIV-1 infection. Acta Paediatr. 1994;83:1029-1034

6. Saavedra JM, Henderson RA, Perman JA, Hutton N, Livingston RA, Yolken RH. Longitudinal assessment of growth in children born to mothers with human immunodeficiency virus infection. Arch Pediatr Adolesc Med. 1995;149:497-502

7. Lepage P, Msellati P, Hitimana DG, et al. Growth of human immunodeficiency type 1-infected and uninfected children: a prospective cohort study in Kigali, Rwanda, 1988 to 1993. Pediatr Infect Dis J. 1996;15: $479-485$

8. Agostoni C, Riva E, Gianni ML, Silano M, Giovannini M, Zuccotti GV. Anthropometric indicators of human immunodeficiency virus infection in infants with early and late symptoms in the first months of life. Eur J Pediatr. 1998;157:811-813

9. Henderson RA, Saavedra JM, Perman JA, Hutton N, Livingston RA, Yolken RH. Effect of enteral tube feeding on growth of children with symptomatic human immunodeficiency virus infection. J Pediatr Gastroenterol Nutr. 1994;18:429-434

10. Miller TL, Awnetwant EL, Evans S, Morris VM, Vazquez IM, McIntosh K. Gastrostomy tube supplementation for HIV-infected children. Pediatrics. 1995;96:696-702

11. Pollack H, Kuchiu A, Cowan L, et al. Neurodevelopment, growth and viral load in HIV-infected infants. Brain Behav Immunol. 1996;10:298-312

12. Grinspoon SK, Donovan DS, Jr, Bilezikian JP. Aetiology and pathogenesis of hormonal and metabolic disorders in HIV infection. Baillieres Clin Endocrinol Metab. 1994;8:735-755

13. Grunfeld C, Pang M, Shimizu L, Shigenaga JK, Jensen P, Feingold KR. Resting energy expenditure, caloric intake, and short-term weight change in human immunodeficiency virus infection and the acquired immunodeficiency syndrome. Am J Clin Nutr. 1992;55:455-460

14. Pizzo PA. Treatment of human immunodeficiency virus-infected infants and young children with dideoxynucleosides. Am J Med. 1990;88: 16S-19S

15. Tovo PA, de Martino M, Gabiano C, et al. Prognostic factors and survival in children with perinatal HIV-1 infection. The Italian Register for HIV Infections in Children. Lancet. 1992;339:1249-1253

16. McKinney RE Jr, Wilfert C. Growth as a prognostic indicator in children with human immunodeficiency virus infection treated with zidovudine. AIDS Clinical Trials Group Protocol 043 Study Group. J Pediatr. 1994; 125:728-733

17. Berhane R, Bagenda D, Marum L, et al. Growth failure as a prognostic indicator of mortality in pediatric HIV infection. Pediatrics. 1997;100(1). Available at: http://www.pediatrics.org/cgi/content/full/100/1/e7

18. Carey VJ, Yong FH, Frenkel LM, McKinney RE Jr. Pediatric AIDS prognosis using somatic growth velocity. AIDS. 1998;12:1361-1369

19. Lindsey JC, Hughes MD, McKinney RE Jr, et al. Treatment-mediated changes in human immunodeficiency virus (HIV) type 1 RNA and CD4 cell counts as predictors of weight growth failure, cognitive decline and survival in HIV-infected children. J Infect Dis. 2000;182:1385-1393

20. Brettler DB, Forsberg A, Bolivar E, Brewster F, Sullivan J. Growth failure as a prognostic indicator for progression to acquired immunodeficiency syndrome in children with hemophilia. J Pediatr. 1990;117:584-588 
21. Scott GB, Hutto C, Makuch RW, et al. Survival in children with perinatally acquired human immunodeficiency virus type 1 infection. N Engl J Med. 1989;321:1791-1796

22. Ogino MT, Dankner WM, Spector SA. Development and significance of zidovudine resistance in children infected with human immunodeficiency virus. J Pediatr. 1993;123:1-8

23. Mofenson L, Moye J, Nugent R, Bethel J, Korelitz J. Relation of mortality risk to select pediatric HIV disease progression endpoints (DPE) used in pediatric HIV therapeutic trials [abstract 1123]. Presented at the 33rd Interscience Convention on Antimicrobial Agents and Chemotherapy, American Society for Microbiology; October 1993; New Orleans, LA

24. McKinney RE Jr, Maha MA, Connor EM, et al. A multicenter trial of oral zidovudine in children with advanced human immunodeficiency virus disease. The Protocol 043 Study Group. N Engl J Med. 1991;324: 1018-1025

25. d'Arminio Monforte A, Musicco M, Galli M, et al. Italian multicentre study of didanosine compassionate use in advanced HIV infection. Italian BMS-906 Study Group. Eur J Clin Microbiol Infect Dis. 1997;16: 135-142

26. Spector SA. HIV therapy advances. Pediatric antiretroviral choices. AIDS. 1994;8(suppl 3):S15-S18

27. Silva M, Skolnik PR, Gorbach SL, et al. The effect of protease inhibitors on weight and body composition in HIV- infected patients. AIDS. 1998;12:1645-1651

28. Miller TL, Mawn BE, Orav EJ, et al. The effect of protease inhibitor therapy on growth and body composition in human immunodeficiency virus type 1-infected children. Pediatrics. 2001;107(5). Available at: http://www.pediatrics.org/cgi/content/full/107/5/e77

29. Dreimane D, Nielsen K, Deveikis A, Bryson YJ, Geffner ME. Effect of protease inhibitors combined with standard antiretroviral therapy on linear growth and weight gain in human immunodeficiency virus type 1-infected children. Pediatr Infect Dis J. 2001;20:315-316

30. Melvin AJ, Mohan KM, Arcuino LA, Edelstein RE, Frenkel LM. Clinical, virologic and immunologic responses of children with advanced human immunodeficiency virus type 1 disease treated with protease inhibitors. Pediatr Infect Dis J. 1997;16:968-974

31. Nadal D, Steiner F, Cheseaux JJ, Rudin C. Ritonavir promotes increased growth in HIV-infected children. Paediatric AIDS Group of Switzerland [letter]. AIDS. 1998;12:2356-2357

32. Van Rossum AMC, Niesters HGM, Geelen SPM, et al. Clinical and virlogic response to combination treatment with indinavir, zidovudine, and lamivudine in children with human immunodeficiency virus-1 infection: a multicenter study in The Netherlands. J Pediatr. 2000;136: $780-788$

33. Rolland-Cachera MF, Bellisle F, Sempe M. The prediction in boys and girls of the weight/height index and various skinfold measurements in adults. Int J Obes Relat Metab Disord. 1989;13:305-311
34. Van Wieringen JC, Roede MJ, Wit JM. Growth diagrams for patient care. Tijdschr Kindergeneeskd. 1985;53:147-1152

35. Cole TJ, Freeman JV, Preece MA. Body mass index reference curves for the UK, 1990. Arch Dis Child. 1995;73:25-29

36. Wade A, Ades A. Age-related reference ranges: significance tests for models and confidence intervals for centiles. Stat Med. 1994;13: 2359-2367

37. Triques K, Coste J, Perret J, et al. Efficiencies of four versions of the Amplicor HIV-1 Monitor test for quantification of different subtypes of human immunodeficiency virus type 1. J Clin Microbiol. 1999;37:110-116

38. Centers for Disease Control and Prevention. Revised classification system for human imunodeficiency virus infection in children less than 13 years of age. Official authorized addenda: human immunodeficiency virus infection codes and official guidelines for coding and reporting ICD-9-CM. MMWR Morb Mortal Wkly Rep. 1994;43:1-19

39. Prader A, Tanner JM, Von Harnach GA. Catch-up growth following illness or starvation: an example of developmental canalization in man. J Pediatr. 1963;62:646-659

40. Kline MW, Van Dyke RB, Lindsey JC, et al. A randomized comparative trial of stavudine (d4T) versus zidovudine (ZDV, AZT) in children with human immunodeficiency virus infection. AIDS Clinical Trials Group 240 Team. Pediatrics. 1998;101:214-220

41. Butler K, Husson R, Balis F. Dideoxyinosine in children with symptomatic human immunodeficiency virus infection. N Engl J Med. 1991;324: 137-144

42. Bakshi SS, Britto P, Capparelli E, et al. Evaluation of pharmacokinetics, safety, tolerance, and activity of combination of zalcitabine and zidovudine in stable, zidovudine-treated pediatric patients with human immunodeficiency virus infection. AIDS Clinical Trials Group Protocol 190 Team. I Infect Dis. 1997;175:1039-1050

43. Solder B, Wintergerst U, Notheis G, Eberle J, Gurtler L, Belohradsky BH. Effect of antiretroviral combination therapy (zidovudine/didanosine or zidovudine/lamivudine) on quantitative plasma human immunodeficiency virus-ribonucleic acid in children and adolescents infected with human immunodeficiency virus. J Pediatr. 1997;130:293-299

44. Gungor T, Funk M, Linde R, et al. Combined therapy in human immunodeficiency virus-infected children-a 4-year experience. Eur J Pediatr. 1993;152:650-654

45. Lewis LL, Venzon D, Church J, et al. Lamivudine in children with human immunodeficiency virus infection: a phase I/II study. The National Cancer Institute Pediatric Branch-Human Immunodeficiency Virus Working Group. J Infect Dis. 1996;174:16-25

46. Pediatric European Network for Treatment of AIDS. A randomized double-blind trial of the addition of lamivudine or matching placebo to current nucleoside analogue reverse transcriptase inhibitor therapy in HIV-infected children: the PENTA-4 trial. AIDS. 1998;12:F151-F160 


\section{Treatment With Highly Active Antiretroviral Therapy in Human Immunodeficiency Virus Type 1-Infected Children Is Associated With a Sustained Effect on Growth}

Gwenda Verweel, Annemarie M. C. van Rossum, Nico G. Hartwig, Tom F. W. Wolfs, Henriëtte J. Scherpbier and Ronald de Groot

Pediatrics 2002;109;25-

DOI: $10.1542 /$ peds.109.2.e25

This information is current as of November 20, 2006

Updated Information
\& Services
Subspecialty Collections
Permissions \& Licensing
Reprints

Updated Information

Reprints including high-resolution figures, can be found at: http://www.pediatrics.org/cgi/content/full/109/2/e25

This article, along with others on similar topics, appears in the following collection(s):

Infectious Disease \& Immunity

http://www.pediatrics.org/cgi/collection/infectious_disease

Information about reproducing this article in parts (figures, tables) or in its entirety can be found online at: http://www.pediatrics.org/misc/Permissions.shtml

Information about ordering reprints can be found online: http://www.pediatrics.org/misc/reprints.shtml 